\title{
ChemComm
}

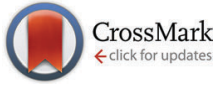

Cite this: Chem. Commun., 2016, 52,7390

Received 31st March 2016, Accepted 4th May 2016

DOI: $10.1039 / \mathrm{c} 6 \mathrm{cc} 02721 \mathrm{k}$

www.rsc.org/chemcomm

\section{A decahaem cytochrome as an electron conduit in protein-enzyme redox processes $\dagger$}

\author{
Chong-Yong Lee, $+\S^{a}$ Bertrand Reuillard, $\ddagger^{a}$ Katarzyna P. Sokol, ${ }^{a}$ \\ Theodoros Laftsoglou, ${ }^{\mathrm{b}}$ Colin W. J. Lockwood, ${ }^{c}$ Sam F. Rowe, ${ }^{c}$ Ee Taek Hwang, ${ }^{\mathrm{b}}$ \\ Juan C. Fontecilla-Camps, ${ }^{d}$ Lars J. C. Jeuken, ${ }^{* b}$ Julea N. Butt*c and \\ Erwin Reisner*a
}

The decahaem cytochrome MtrC from Shewanella oneidensis MR-1 was employed as a protein electron conduit between a porous indium tin oxide electrode and redox enzymes. Using a hydrogenase and a fumarate reductase, $\mathrm{MtrC}$ was shown as a suitable and efficient diode to shuttle electrons to and from the electrode with the MtrC redox activity regulating the direction of the enzymatic reactions.

Protein-protein interactions are key processes operating in cells and organisms to regulate metabolisms and signalling. ${ }^{1}$ More specifically, the interactions of redox proteins with redox enzymes enable electron circulation and catalytic processes. ${ }^{2}$ Shewanella oneidensis MR-1 has become an organism of particular interest to study these redox processes, as it possesses a complex machinery of redox proteins situated in the periplasm as well as inner and outer membranes of the cell. ${ }^{3}$ These proteins enable efficient transfer of electrons from the inside to the outside of the cell and deliver them to extracellular acceptors such as metal oxide minerals to provide the cell colony with alternative growth conditions. ${ }^{4,5}$

The presence of outer membrane cytochromes (OMCs) on the surface of the cell creates the possibility to electrically wire them to different types of electrode materials, facilitating bidirectional electron transfer, ${ }^{6-8}$ which is being exploited in the development of bacterial anodes for microbial fuel cells or the cathodic reduction of organic substrates like fumarate..$^{9-11}$ Recently, several

\footnotetext{
${ }^{a}$ Department of Chemistry, University of Cambridge, Lensfield Road,

Cambridge CB2 1EW, UK. E-mail: reisner@ch.cam.ac.uk

${ }^{b}$ School of Biomedical Sciences and the Astbury Centre, University of Leeds, Leeds, LS2 9JT, UK. E-mail: l.j.c.jeuken@leeds.ac.uk

${ }^{c}$ School of Chemistry, University of East Anglia, Norwich Research Park, Norwich, NR4 7TJ, UK. E-mail: j.butt@uea.ac.uk

${ }^{d}$ Metalloproteins Unit, Institut de Biologie Structurale, CEA, CNRS, Université Grenoble Alpes, 38044 Grenoble, France

$\dagger$ Electronic supplementary information (ESI) available: See DOI: 10.1039/c6cc02721k. Additional data related to this publication are available at the University of Cambridge data repository (https://www.repository.cam.ac.uk/handle/1810/255902).

\$ These authors contributed equally to this work.

$\S$ Current address: ARC Centre of Excellence for Electromaterials Science, Intelligent Polymer Research Institute/AIIM Faculty, Innovation Campus, University of Wollongong, NSW 2522, Australia.
}

reports demonstrated that it is also possible to wire this organism onto electrodes within a photoelectrochemical cell either by connecting them onto a carbon or semiconducting electrode material. ${ }^{12,13}$

OMCs as electron conduits have also been studied over the past few years due to their ability to facilitate electron transfer and the possibility to use them as electron relays for bioenergy production or storage. ${ }^{14-16}$ Moreover, MtrC, a decahaem OMC protein from Shewanella oneidensis MR-1, has recently been used to collect electrons from a ruthenium based photosensitiser and transport them to an electrode in a dye-sensitised photoanode. ${ }^{17}$ These results highlight the possibility to mimic the efficient charge separation processes in natural photosynthetic organisms, which is a major challenge in numerous molecular or enzymatic photocatalytic applications. ${ }^{18-21}$ Electrochemical coupling of isolated MtrC to enzyme activity has not yet been described and would therefore enable the development of lightdriven catalytic reactions with OMCs in vitro and, in the longer term, in a biological setting.

Herein, we describe the coupling of MtrC as a protein electron relay to enzymes to catalyse oxidative and reductive processes on a porous indium tin oxide electrode (Fig. 1). Porous ITO electrodes allow high protein loading, high conductivity along with good optical transparency to perform electrochemistry and spectroelectrochemistry (SEC). ${ }^{22-25}$ MtrC displays a large redox window (between 0 and $-0.4 \mathrm{~V}$ vs. SHE at $\mathrm{pH} 7)^{14}$ due to the presence of 10 haems within its structure. The immobilised MtrC and two redox active enzymes were used to assess the feasibility to transfer electrons with MtrC as redox relay for both anodic and cathodic catalytic processes (Fig. 1). [NiFeSe]-hydrogenase from Desulfomicrobium baculatum $\left(\mathrm{H}_{2}\right.$ ase $)$ and fumarate reductase (FccA), a flavocytochrome from S. oneidensis, were used for $\mathrm{H}_{2}$ oxidation and fumarate reduction, respectively (see ESI $\dagger$ for details about isolation and characterisation). These enzymes were selected due to the ideal position of their catalytic onset potential $\left(-0.42 \mathrm{~V}\right.$ and $-0.04 \mathrm{~V} v s$. SHE at $\mathrm{pH} 7$ for $\mathrm{H}_{2}$ oxidation and fumarate reduction, respectively) as well as their particular interest in the field of solar energy conversion. ${ }^{26-28}$ 


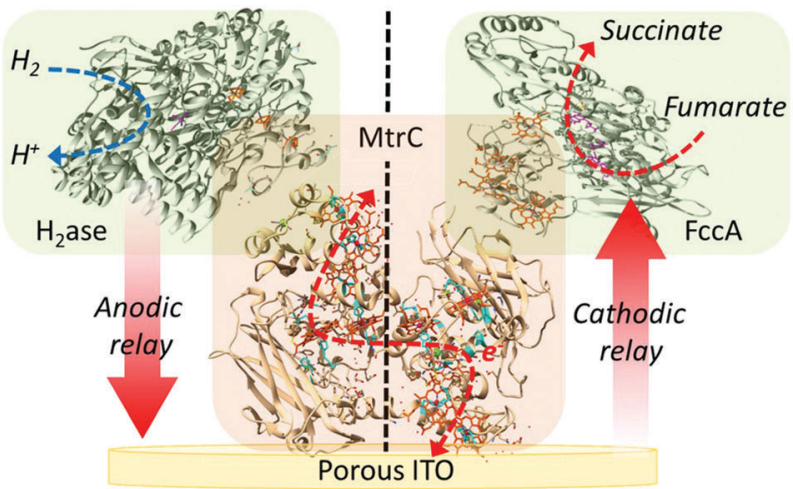

Fig. 1 Schematic representation of the catalytic redox pathways with hydrogenase $\left(\mathrm{H}_{2}\right.$ ase) and fumarate reductase (FccA) using MtrC as an electron relay between the enzymes and a porous ITO electrode.

In order to investigate the possibility of studying electrocatalytic transformations through protein-enzyme interactions, we firstly adsorbed $\mathrm{MtrC}$ ( $3 \mu \mathrm{L}$ of $40 \mu \mathrm{M}$ solution) onto a $2 \mu \mathrm{m}$ thick IOmesoITO electrode $\left(0.25 \mathrm{~cm}^{2}\right.$ geometrical surface area), which contains a macroporous inverse opal (IO) morphology (approximately $750 \mathrm{~nm}$ pore diameter) with a mesoporous skeleton (ITO particle size less than $50 \mathrm{~nm}$; see ESI $\dagger$ for detailed information). ${ }^{29}$ Excess protein was removed by rinsing the electrode with the electrolyte solution (mixed buffer $\mathrm{pH} 7$ ) and the electrochemical response of the adsorbed protein was then recorded at $\mathrm{pH}$ 7. The resulting protein film voltammogram (PFV) depicts broad but reversible redox waves between 0 and $-0.38 \mathrm{~V} v$ s. SHE, which is consistent with the previously reported succession of redox processes coming from the ten haems within the MtrC structure (Fig. 2a). ${ }^{14}$ Thus, the MtrC haems can be electrically wired onto the ITO electrode. From the integration of the $\mathrm{Fe}^{2+}$ to $\mathrm{Fe}^{3+}$ oxidation wave of the PFV scans, the charge was calculated per geometrical surface area and the amount of electrochemically wired haems was estimated to be approximately $1.4 \mathrm{nmol}$ haem $\mathrm{cm}^{-2}$, which corresponds to $0.14 \mathrm{nmol} \mathrm{MtrC} \mathrm{cm}^{-2}$.
We subsequently investigated the possibility to electrically wire enzymes via the MtrC decahaem electron conduit to the ITO electrode. The same MtrC-modified electrode was prepared (IOmesoITO|MtrC), followed by drop-casting of $\mathrm{H}_{2}$ ase ( $3 \mu \mathrm{L}$ of $8 \mu \mathrm{M}$ solution) or FccA ( $3 \mu \mathrm{L}$ of $32 \mu \mathrm{M}$ solution).

First, the extraction of electrons from $\mathrm{H}_{2}$ ase through $\mathrm{H}_{2}$ oxidation was investigated. The onset potential of $\mathrm{H}_{2}$ oxidation with $\mathrm{H}_{2}$ ase $(-0.42 \mathrm{~V} v$ s. SHE) is located below the redox active window of MtrC, allowing thermodynamically for a catalytic oxidative process to occur. The PFVs (Fig. 2b) of IOmesoITO $|\mathrm{MtrC}| \mathrm{H}_{2}$ ase and IOmesoITO $\mid \mathrm{H}_{2}$ ase (where the $\mathrm{H}_{2}$ ase is directly adsorbed on ITO) show the electrocatalytic activity of the $\mathrm{H}_{2}$ ase for both the reduction of protons and the oxidation of $\mathrm{H}_{2}$. With IOmesoITO| $\mathrm{H}_{2}$ ase, the catalytic onset $\left(E_{\text {onset }}\right)$ for $\mathrm{H}_{2}$ oxidation is observed at the predicated potential of approximately $-0.42 \mathrm{~V} v$ s. SHE, with a current density $(I)$ of $0.87 \mathrm{~mA} \mathrm{~cm}{ }^{-2}$ at $-0.2 \mathrm{~V}$ vs. SHE. The reversibility of $\mathrm{H}_{2} / \mathrm{H}^{+}$interconversion with $\mathrm{H}_{2}$ ase is illustrated by the same $E_{\text {onset }}$ of $-0.42 \mathrm{~V} v s$. SHE for catalytic proton-reduction with an $I=-0.35 \mathrm{~mA} \mathrm{~cm}{ }^{-2}$ obtained at $-0.6 \mathrm{~V}$ vs. SHE. For the IOmesoITO $|\mathrm{MtrC}| \mathrm{H}_{2}$ ase electrode, an $E_{\text {onset }}$ of $-0.42 \mathrm{~V}$ vs. SHE was obtained for $\mathrm{H}_{2}$ oxidation with $I=0.71 \mathrm{~mA} \mathrm{~cm}^{-2}$ at $-0.2 \mathrm{~V} v s$. SHE. In contrast, catalytic proton reduction was almost entirely switched off in the presence of MtrC and only $I=0.08 \mathrm{~mA} \mathrm{~cm}^{-2}$ was obtained at $-0.6 \mathrm{~V} v$ s. SHE. The difference in catalytic bias for the two electrodes can be attributed to the interleaved MtrC. The diode-effect of MtrC can be explained by its redox couples, which make it essentially an insulator when a potential more negative than its redox active window is applied. All haems are reduced at $-0.35 \mathrm{~V} v s$. SHE and this potential is not sufficiently negative to reduce protons even with a reversible electrocatalyst (and hence the absence of a significant cathodic current). However, the MtrC haems are sufficiently oxidising to extract electrons from $\mathrm{H}_{2}$ ase to support catalytic $\mathrm{H}_{2}$ oxidation.

Due to its ability to reduce fumarate to succinate at low overpotential $\left(E_{\text {onset }}=-0.04 \mathrm{~V} v\right.$ s. SHE $)$ at its flavin adenine dinucleotide (FAD) site, ${ }^{28,30}$ the redox active window of FccA is
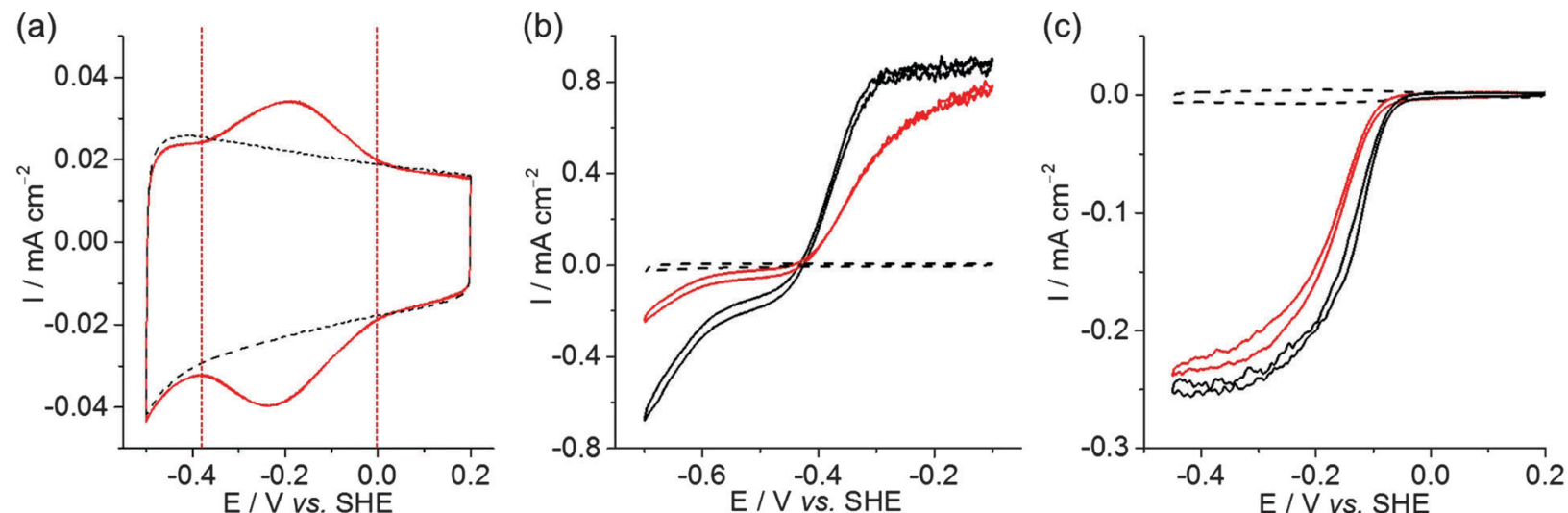

Fig. 2 PFVs of (a) protein-free IOmesolTO (dashed black trace) and IOmesolTO|MtrC (solid red trace), (b) protein-free IOmesolTO (dashed black trace), IOmesolTO| $\mathrm{H}_{2}$ ase (solid black trace) and IOmesolTO|MtrC| $\mathrm{H}_{2}$ ase (solid red trace) under 1 bar $100 \% \mathrm{H}_{2}$ and (c) IOmesolTO|MtrC|FccA in absence of fumarate (dashed black trace), IOmesolTO|FccA (solid black trace) and IOmesolTO|MtrC|FccA (solid red trace) in the presence of $1 \mathrm{mM}$ of fumarate. General conditions: a $2 \mu \mathrm{m}$ thick 1 OmesolTO electrode in a mixed buffer electrolyte solution at $\mathrm{pH} 7\left(25 \pm 2{ }^{\circ} \mathrm{C}\right)$ and under stirring at a scan rate $(\nu)$ of $10 \mathrm{mV} \mathrm{s}^{-1}$ was employed. 
sufficiently positive to predict that it may receive electrons from MtrC (Fig. 1). The electrodes were prepared analogously to the $\mathrm{H}_{2}$ ase electrodes by using FccA as the enzyme. PFV of an IOmesolTO electrode coated with MtrC and then FccA (IOmesoITO|MtrC|FccA) and solely FccA (IOmesoITO|FccA) at $\mathrm{pH} 7$ with $1 \mathrm{mM}$ fumarate is shown in Fig. 2c. A catalytic wave for the reduction of fumarate to succinate $^{28}$ is observed for both electrodes, reaching $I=0.23$ and $0.25 \mathrm{~mA} \mathrm{~cm}^{-2}$ at $-0.4 \mathrm{~V}$ vs. SHE for IOmesoITO|MtrC|FccA and IOmesoITO $\mid \mathrm{FccA}$, respectively. However, a significant shift in $E_{\text {onset }}$ is observed: IOmesoITO|FccA displays an $E_{\text {onset }}$ of $-0.04 \mathrm{~V} v s$. SHE, whereas mesoITO $|\mathrm{MtrC}| \mathrm{FccA}$ shows an $E_{\text {onset }}$ of approximately $-0.08 \mathrm{~V}$ vs. SHE. This difference in $E_{\text {onset }}$ is due to the presence of the MtrC, which regulates the electron transfer potential. In the case of the IOmesoITO|MtrC|FccA electrode, the electrons are shuttled from the ITO to the enzyme through the protein conduit underlining the good electronic communication of MtrC with the electrode as well as with FccA. This demonstrates the ability of MtrC to interact with another haem/flavin containing enzyme and transfer electrons that can be used to perform reductive transformations.

UV-Vis SEC was used as complementary analytical tool to further investigate the immobilisation of MtrC onto the electrode and the catalytic processes of the different bioelectrodes. As above, MtrC ( $3 \mu \mathrm{L}$ of $40 \mu \mathrm{M}$ solution) and FccA ( $3 \mu \mathrm{L}$ of $32 \mu \mathrm{M}$ solution) were drop-cast onto a mesoporous ITO electrode (mesoITO; see $\mathrm{ESI} \dagger$ for details) surface and then rinsed with electrolyte solution. MesoITO was used instead of IOmesoITO for SEC experiments as a clearer spectroscopic signal was observed from the adsorbed proteins. UV-Vis spectra were recorded for mesoITO|MtrC|FccA, mesoITO $\mid$ MtrC and mesoITO|FccA in transmission mode, while the electrodes were poised at different potentials (from 0.1 to $-0.45 \mathrm{~V} v s$. SHE).

An excellent communication between the haem units in MtrC and FccA and ITO was observed for all three electrodes (Fig. S1, $\mathrm{ESI} \dagger$ ). At $0.1 \mathrm{~V} v s$. SHE, the UV-Vis spectra depict the characteristic signals of the $\mathrm{Fe}^{3+}$-haems with an intense band at $410 \mathrm{~nm}$ and a broad signal between 500 and $600 \mathrm{~nm}$. Stepping towards more negative potentials decreases the intensity of the bands arising from $\mathrm{Fe}^{3+}$-haem and new signals grow at 419, 520 and $550 \mathrm{~nm}$ that correspond to $\mathrm{Fe}^{2+}$-haem. At $-0.45 \mathrm{~V} v$ s. SHE, the intensity of these new peaks stabilises, indicating the total reduction of the haems of the immobilised proteins. ${ }^{14,23}$ From these UV-Vis spectra, an isosbestic point is observed at $412 \mathrm{~nm}$ for mesolTO|MtrC, mesoITO $\mid$ FccA and mesoITO $\mid$ MtrC $\mid$ FccA electrodes, indicating a clean $\mathrm{Fe}^{3+} / \mathrm{Fe}^{2+}$ interconversion.

These mesoITO electrodes were also studied by protein film voltammetry to quantify the amounts of protein immobilised and electrically wired to the surface (Fig. S2, ESI $\dagger$ ). From integration of the oxidation wave the number of electrons exchanged with the electrode could be estimated and converted to electro-active protein coverage by appropriate consideration of the number, and electron stoichiometry, of the relevant redox cofactors. Approximately $1.5 \mathrm{nmol}$ electrons $\mathrm{cm}^{-2}$ were exchanged by MtrC with ten haems corresponding to $0.15 \mathrm{nmol} \mathrm{cm}{ }^{-2}$ of MtrC. Approximately $0.6 \mathrm{nmol}$ electrons $\mathrm{cm}^{-2}$ were exchanged by FccA with four haems and one

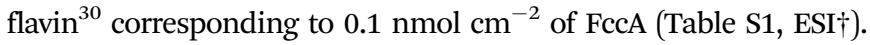

These values suggest that similar amounts of FccA and MtrC are immobilised on the mesoITO electrodes, which is consistent with the similar dimensions of these globular proteins, $75 \mathrm{kDa}$ and $64 \mathrm{kDa}$ for MtrC and FccA, respectively. ${ }^{16} \mathrm{PFV}$ of mesolTO|MtrC|FccA indicates that $1.9 \mathrm{nmol}$ electrons $\mathrm{cm}^{-2}$ were exchanged between the protein film and the electrode. This corresponds to roughly the sum of the charges passed by the MtrC and the FccA films (see above) and is consistent with the presence of roughly equal amounts of MtrC and FccA on the mesoITO $\mid$ MtrC|FccA electrode.

The same trend was observed with the SEC experiments (Fig. S1, ESI $\dagger$ ). The $410 \mathrm{~nm}$ band corresponding to the $\mathrm{Fe}^{3+}$ haem shows an absorbance of 0.26 for mesoITO|MtrC, whereas it reaches 0.09 for the mesoITO|FccA electrode. The absorbance of the equivalent spectral feature from the mesoITO $|\mathrm{MtrC}| \mathrm{FccA}$ electrode is $\mathbf{0 . 3 5}$, which corresponds to the addition of absorbance values from mesoITO|MtrC and mesoITO|FccA. Also, the absorbance of mesoITO $\mid \mathrm{FccA}$ is equivalent to $35 \%$ of the absorbance of the mesoITO|MtrC, which corresponds to the $40 \%$ haem ratios between FccA ( 4 haems) and MtrC (10 haems) (Table S1, ESI $\dagger$ ). These experiments support that a near $1: 1$ ratio of MtrC:FccA is obtained and that FccA can strongly interact physically and electrically with MtrC.

SEC was then used to assess the catalytic activity of the electrodes. PFVs were recorded while monitoring the absorbance at $419 \mathrm{~nm}$ with the FccA directly on mesoITO or with an interfacial MtrC layer in absence and in presence of $10 \mathrm{mM}$ of fumarate (Fig. 3). This concentration of fumarate is considerably higher than the reported $K_{\mathrm{M}}$ for FccA. ${ }^{30}$ As a consequence, the catalytic PFV should be relatively free from significant limitation by mass transport (substrate or product diffusion to immobilised enzyme) and the electrocatalytic response should be determined by the electrical communication between the catalytic site and the electrode.

Fig. 3 also shows the voltabsorptometry of FccA on mesoITO and mesoITO|MtrC, where the absorbance of the band appearing at $419 \mathrm{~nm}$ is monitored while the applied potential is varied. In the absence of fumarate, the maximum absorbance is obtained for the electrodes when all haems are fully reduced below $-0.45 \mathrm{~V}$ with a higher absolute absorbance for mesoITO|MtrC|FccA because more haems are present per geometrical surface area

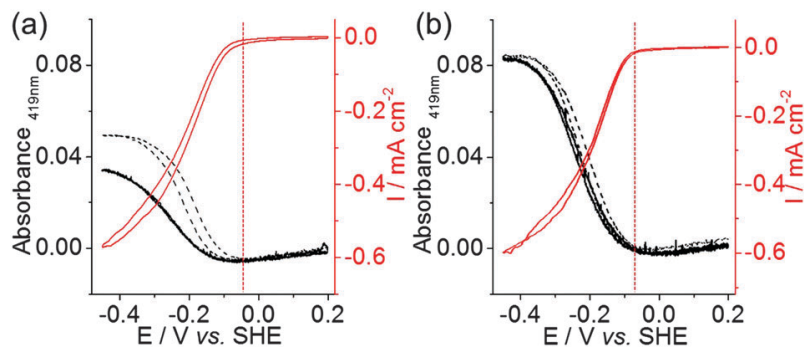

Fig. 3 Voltabsorptometry (at $419 \mathrm{~nm}$; black; left axis) and PFV (red; right axis) of (a) mesolTO|FccA and (b) mesolTO|MtrC|FccA electrode in absence (dashed black trace) and presence (solid black trace and solid red trace) of $10 \mathrm{mM}$ of fumarate at $\mathrm{pH} 7\left(\nu=10 \mathrm{mV} \mathrm{s}^{-1}\right)$ in a $\mathrm{pH} 7$ electrolyte solution $\left(25 \pm 2{ }^{\circ} \mathrm{C}\right)$. PFVs give a similar catalytic response for mesolTO and IOmesolTO (see Fig. 2). 
of the electrode (see above). There is no change to the absorbancepotential profile when $10 \mathrm{mM}$ fumarate is introduced to the experiment with mesoITO $\mid$ MtrC|FccA, suggesting that electrons are delivered from the electrode to all haems more rapidly than they are removed by reoxidation associated with fumarate reduction. Thus, wiring of FccA to the electrode via the interleaved MtrC is very effective. In contrast, addition of $10 \mathrm{mM}$ fumarate lowers the magnitude of the absorbance-potential profile for the mesoITO|FccA electrode. Haem oxidation coupled to fumarate reduction is faster than haem reduction by the electrode, which suggests that direct wiring of FccA to the electrode is less effective than wiring via MtrC.

In summary, we have demonstrated that electrocatalytic processes can be accomplished through an electrode-proteinenzyme interface and that the catalytic reaction can be tuned in one preferential direction. MtrC could be successfully used as an electron relay and has been shown to electrically wire both oxidation and reduction processes of enzymatic catalysts. Depending on the relative redox potentials of the enzymes, this decahaem protein showcases a diode effect as equivalent to an electronic gate, shutting down reduction pathways that are below and preventing oxidation processes above its redox window. Importantly, SEC suggests that interleaved MtrC improves the electronic coupling between FccA and the ITO electrode and MtrC is therefore able to engage in effective electron exchange with redox enzymes that are not its partners in the cellular context. Along with recent results showing the photo-induced switching effect, ${ }^{17}$ this study is a step forward towards the use of natural molecular electronic relays such as MtrC to electrically wire photosensitisers and enzymatic catalysts towards the development of new catalytic entities.

This work was supported by the BBSRC (BB/K010220/1, BB/K009753/1, BB/K009885/1, DTP studentship to S. F. R.), EPSRC (DTA studentship to K. P. S.), (FP/2007-2013)/ERC Grant no. 280518 (T. L.) and an Intra-European Marie-Curie fellowship (to C. Y. L.). J. N. B. is a Royal Society Leverhulme Trust Senior Research Fellow. We thank Verity Lyall for purification of MtrC and Marina Ianello and Dr Christine Cavazza for isolating and purifying the hydrogenase used in this study.

\section{Notes and references}

1 Q. Bashir, S. Scanu and M. Ubbink, FEBS J., 2011, 278, 1391-1400.

2 K. Sakamoto, M. Kamiya, M. Imai, K. Shinzawa-Itoh, T. Uchida, K. Kawano, S. Yoshikawa and K. Ishimori, Proc. Natl. Acad. Sci. U. S. A., 2011, 108, 12271-12276.

3 J. K. Fredrickson, M. F. Romine, A. S. Beliaev, J. M. Auchtung, M. E. Driscoll, T. S. Gardner, K. H. Nealson, A. L. Osterman, G. Pinchuk,
J. L. Reed, D. A. Rodionov, J. L. M. Rodrigues, D. A. Saffarini, M. H. Serres, A. M. Spormann, I. B. Zhulin and J. M. Tiedje, Nat. Rev. Microbiol., 2008, 6, 592-603.

4 M. Y. El-Naggar, G. Wanger, K. M. Leung, T. D. Yuzvinsky, G. Southam, J. Yang, W. M. Lau, K. H. Nealson and Y. A. Gorby, Proc. Natl. Acad. Sci. U. S. A., 2010, 107, 18127-18131.

5 D. J. Richardson, J. N. Butt, J. K. Fredrickson, J. M. Zachara, L. Shi, M. J. Edwards, G. White, N. Baiden, A. J. Gates, S. J. Marritt and T. A. Clarke, Mol. Microbiol., 2012, 85, 201-212.

6 A. A. Carmona-Martínez, F. Harnisch, U. Kuhlicke, T. R. Neu and U. Schröder, Bioelectrochemistry, 2013, 93, 23-29.

7 X.-W. Liu, J.-J. Chen, Y.-X. Huang, X.-F. Sun, G.-P. Sheng, D.-B. Li, L. Xiong, Y.-Y. Zhang, F. Zhao and H.-Q. Yu, Sci. Rep., 2014, 4, 3732.

8 C. Ding, M. Lv, Y. Zhu, L. Jiang and H. Liu, Angew. Chem., Int. Ed., 2015, 54, 1446-1451.

9 S. R. Higgins, C. Lau, P. Atanassov, S. D. Minteer and M. J. Cooney, ACS Catal., 2011, 1, 994-997.

10 J. N. Roy, S. Babanova, K. E. Garcia, J. Cornejo, L. K. Ista and P. Atanassov, Electrochim. Acta, 2014, 126, 3-10.

11 D. E. Ross, J. M. Flynn, D. B. Baron, J. A. Gralnick and D. R. Bond, PLoS One, 2011, 6, e16649.

12 H. Wang, F. Qian, G. Wang, Y. Jiao, Z. He and Y. Li, ACS Nano, 2013, 7, 8728-8735.

13 F. Qian, H. Wang, Y. Ling, G. Wang, M. P. Thelen and Y. Li, Nano Lett., 2014, 14, 3688-3693.

14 R. S. Hartshorne, C. L. Reardon, D. Ross, J. Nuester, T. A. Clarke, A. J. Gates, P. C. Mills, J. K. Fredrickson, J. M. Zachara, L. Shi, A. S. Beliaev, M. J. Marshall, M. Tien, S. Brantley, J. N. Butt and D. J. Richardson, Proc. Natl. Acad. Sci. U. S. A., 2009, 106, 22169-22174.

15 M. Firer-Sherwood, G. S. Pulcu and S. J. Elliott, J. Biol. Inorg. Chem., 2008, 13, 849-854.

16 M. Breuer, K. M. Rosso, J. Blumberger and J. N. Butt, J. R. Soc., Interface, 2015, 12, 20141117.

17 E. T. Hwang, K. Sheikh, K. L. Orchard, D. Hojo, V. Radu, C.-Y. Lee, E. Ainsworth, C. Lockwood, M. A. Gross, T. Adschiri, E. Reisner, J. N. Butt and L. J. C. Jeuken, Adv. Funct. Mater., 2015, 25, 2308-2315.

18 A. J. Cowan and J. R. Durrant, Chem. Soc. Rev., 2013, 42, 2281-2293.

19 T. W. Woolerton, S. Sheard, E. Reisner, E. Pierce, S. W. Ragsdale and F. A. Armstrong, J. Am. Chem. Soc., 2010, 132, 2132-2133.

20 K. A. Brown, M. B. Wilker, M. Boehm, G. Dukovic and P. W. King, J. Am. Chem. Soc., 2012, 134, 5627-5636.

21 C. A. Caputo, M. A. Gross, V. W. Lau, C. Cavazza, B. V. Lotsch and E. Reisner, Angew. Chem., Int. Ed., 2014, 53, 11538-11542.

22 M. Kato, T. Cardona, A. W. Rutherford and E. Reisner, J. Am. Chem. Soc., 2013, 135, 10610-10613.

23 S. J. Marritt, G. L. Kemp, L. Xiaoe, J. R. Durrant, M. R. Cheesman and J. N. Butt, J. Am. Chem. Soc., 2008, 130, 8588-8589.

24 C. Renault, C. P. Andrieux, R. T. Tucker, M. J. Brett, V. Balland and B. Limoges, J. Am. Chem. Soc., 2012, 134, 6834-6845.

25 P. A. Ash and K. A. Vincent, Chem. Commun., 2012, 48, 1400-1409.

26 W. Lubitz, H. Ogata, O. Rüdiger and E. Reijerse, Chem. Rev., 2014, 114, 4081-4148.

27 C. Wombwell, C. A. Caputo and E. Reisner, Acc. Chem. Res., 2015, 48, 2858-2865.

28 A. Bachmeier, B. J. Murphy and F. A. Armstrong, J. Am. Chem. Soc., 2014, 136, 12876-12879.

29 D. Mersch, C.-Y. Lee, J. Z. Zhang, K. Brinkert, J. C. Fontecilla-Camps, A. W. Rutherford and E. Reisner, J. Am. Chem. Soc., 2015, 137, 8541-8549.

30 K. L. Turner, M. K. Doherty, H. A. Heering, F. A. Armstrong, G. A. Reid and S. K. Chapman, Biochemistry, 1999, 38, 3302-3309. 